University of New Hampshire

University of New Hampshire Scholars' Repository

Law Faculty Scholarship

University of New Hampshire - Franklin Pierce

School of Law

$1-1-2010$

\title{
Algae and Biodiesel: Patenting Energized as Green Goes Commercial
}

Matthew R. Priess

University of New Hampshire School of Law

Stanley P. Kowalski

University of New Hampshire School of Law, stanley.kowalski@law.unh.edu

Follow this and additional works at: https://scholars.unh.edu/law_facpub

Part of the Bioresource and Agricultural Engineering Commons, Energy and Utilities Law Commons, Intellectual Property Law Commons, and the Oil, Gas, and Energy Commons

\section{Comments}

This paper was published in the Journal of Commercial Biotechnology at http://CommercialBiotechnology.com, http://perma.cc/SR5M-52N8

\section{Recommended Citation}

Matthew R. Priess \& Stanley P. Kowalski, "Algae and Biodiesel: Patenting Energized as Green Goes Commercial," 16 J. Comm. Biotech. 293 (2010), available at http://www.palgrave-journals.com/jcb/ journal/v16/n4/pdf/jcb201015a.pdf

This Article is brought to you for free and open access by the University of New Hampshire - Franklin Pierce School of Law at University of New Hampshire Scholars' Repository. It has been accepted for inclusion in Law Faculty Scholarship by an authorized administrator of University of New Hampshire Scholars' Repository. For more information, please contact sue.zago@law.unh.edu. 


\section{Original Article}

\section{Algae and Biodiesel: Patenting energized as green goes commercial}

Received (in revised form): 16th July 2010

\section{Matthew R. Preiss}

is a JD and LLM (Intellectual Property) Candidate at the University of New Hampshire School of Law (formerly the Franklin Pierce Law Center) a PhD Candidate in Chemical Engineering at the University of Rhode Island (URI), and has been working with the International Technology Transfer Institute (ITTI) at the University of New Hampshire School of Law (formerly the Franklin Pierce Law Center) since 2008. Matthew holds a MS in Chemical Engineering from URI, a BS in Biomedical Engineering from Columbia University, and a BS in Chemistry, Physics and Mathematics from Providence College.

\section{Stanley P. Kowalski}

is an assistant professor of Clinical Law and Director of the International Technology Transfer Institute (ITTI) at the University of New Hampshire School of Law (formerly the Franklin Pierce Law Center) in Concord, New Hampshire. ITTI is dedicated to promoting global innovation, with a focus on accelerating access to critical advances in health and agricultural in developing countries. He earned a PhD in plant breeding from Cornell University at the International Service for the Acquisition of Agri-Biotech Applications (ISAAA), he conducted the preliminary freedom-to-operate analysis of (pro-vitamin A) Golden Rice. $\mathrm{He}$ also holds a JD (emphasis in intellectual property) from the University of New Hampshire School of Law (formerly the Franklin Pierce Law Center).

This article discusses the current state of algal biodiesel research and development in the United States. Applicable US patent law is discussed and explained as it applies to algal biodiesel. Representative patents and patent applications of commercial products for algal biodiesel are identified and analyzed.

ABSTRACT In the twenty-first century, predominant dependence on fossil fuels as energy resources will not be sustainable. Developing and commercializing green energy innovations will be an essential component of the transition to a more diversified energy economy. Algal biodiesel is one of the most promising green fuels because of its potential as a renewable and sustainable fuel source without displacing food crops. Algal biodiesel research and development are necessary early steps towards a transition to a green energy economy. The strategic use of strong patent portfolios will drive this by attracting investment, incentivizing innovation and accelerating commercialization. Whereas algal biodiesel research and development is largely still early stage, this will rapidly change as aggressive investments and government subsidies facilitate economically competitive algal biodiesel to enter the energy market. Algal domestication, improvement and industrial utilization for biodiesel production will therefore inevitably create value, leading to increased assertion of property rights, of which intellectual property rights in the form of patents are fundamental. This article provides

Correspondence: Stanley P. Kowalski

International Technology Transfer Institute (ITTI),

University of New Hampshire School of Law, 2 White Street,

Concord, NH 03301, USA

E-mail: stanley.kowalski@law.unh.edu 
a summary of representative patents and patent applications in the algal biodiesel technology space and their commercial applications.

Journal of Commercial Biotechnology (2010) 16, 293-312. doi:10.1057/jcb.2010.15;

published online 14 September 2010

Keywords: biofuel; algae; patent; biodiesel; intellectual property; green energy

\section{INTRODUCTION}

Worldwide concerns over global climate change, national energy security, rising fuel costs and the diminishing supply of inexpensive fossil fuels has stimulated interest in renewable energy resources. Currently, there are few renewable energy resources that can compete directly with petroleum, especially in the transportation sector. ${ }^{1-3}$ Biofuels, such as bioethanol and biodiesel, are emerging as a competitive alternative to petrofuel because they are renewable, have superior environmental benefits, can be produced in sufficient quantities, and provide a positive net energy gain, all factors critical to long-term substitution of fossil fuels.

Biodiesel is an especially interesting substitute for petroleum because it has a positive net energy ratio. Also, B100 (100 per cent biodiesel with no petrodiesel to supplement the mixture) can be utilized as a direct petroleum substitute without major changes to the current infrastructure (engines, storage and distribution). ${ }^{1,3,4}$

Biodiesel comprises methyl esters produced by the transesterification of biomass oils with an alcohol (usually methanol or ethanol). Greater than 350 biomass resources have been identified as a triglyceride source for the production of biodiesel. Table 1 identifies the most commonly investigated feedstocks. Rapeseed, oil palm, soybean and sunflower are the primary feedstocks utilized for the production of biodiesel. ${ }^{3,5}$ Over 90 per cent of biodiesel production worldwide is derived from rapeseed and sunflower oil alone. ${ }^{6}$ Biodiesel is most commonly produced from soybean oil in USA, and rapeseed oil in Europe. ${ }^{5}$

Microalgae (hereinafter algae), unicellular photosynthetic organisms, are particularly attractive as a feedstock as they will not displace agricultural crops, can be grown yearround, and can be harvested continually. Algae are also advantageous as a feedstock because they have a high growth rate, ability to thrive in saline water, capability of sequestering carbon dioxide $\left(\mathrm{CO}_{2}\right)$, and capability to use nutrients (such as nitrogen and phosphorous) from waste products (such as sewage). ${ }^{7}$ Algae typically have a high oil content of $20-50$ per cent (dry weight), some strains having an oil content as high as 80 per cent dry weight. Algae are capable of doubling their biomass in a 24-hour period. Algae can produce 8-24 times the triglycerides per area as other biomass resources, enabling the production of 58700-136900 litre per ha of oil per year. It is estimated that between 2 and 6 per cent of the total US cropping area would be sufficient to produce enough algal oil for biodiesel production to entirely satisfy its transportation fuel needs. ${ }^{8}$

The attractiveness of algae as a feedstock for biodiesel production has led to accelerated development of technologies to harness it as a future major fuel source. These technologies include selection of algal strains, genetic enhancement of algal strains through lipid metabolism and other biotechnological modifications, algaculturing techniques, lipid extraction, and biodiesel processing and production. The rapid domestication and improvement of algae, coupled with advances in algal lipid extraction and processing, are moving this erstwhile mostly ignored (seemingly worthless and frequently a nuisance) resource towards industrial utilization on a very large scale. However, this requires substantial investments in human resources, expertise, capital and time. As value is added, property rights are inevitably asserted, of which 
Table I: Most investigated biodiesel triglyceride sources

\begin{tabular}{ll}
\hline Edible oils & Non-edible oils \\
\hline Almond, Amaranth, Apricot, & Androbia, Babassue Tree, \\
Argan, Artichoke, Avocado, & Bacteria, Bluestem, Camelina, \\
Babassue, Bay Laurel, & Canola (Rapeseed), Castor \\
Beechnut, Beef Tallow, & Bean, Copaifera (Diesel Tree), \\
Borneo Tallow Nut, Carob & Cottonseed, Cumaru, Dammar, \\
Pod, Cashew, Chicken & Fungi, Hemp, Honge, Jatropha, \\
Fat, Coconut, Cohune, & Jojoba, Karanja, Linseed, \\
Coriander Seed, Corn, & Macroalgae, Mahua, Microalgae, \\
False Flax, Flax, Fish, Grape & Milk Bush, Nagchampa, Neem, \\
Seed, Hazelnut, Kapok Seed, & Petroleum Nut, Rubber Tree, \\
Lallematia, Laurel, Lemon & Seaweed, Silk Cotton Tree, \\
Seed, Macadamia, Macauba & Stillingia,Tall,Tobacco Seed, \\
Fruit, Meadowfoam Seed, & Tung, Used Vegetable Oil, \\
Mustard, Okra Seed, & Willow,'Yellow Grease' (Used \\
Olive, Palm, Pecan, Peanut, & Vegetable Oil) \\
Perilla Seed, Pequi, Pork & \\
Lard, Pine Nut, Pistachio, & \\
Poppyseed, Prune Kernel, & \\
Pumpkin, Quinoa, Ramtil, & \\
Radish, Rice Bran, Safflower, & \\
Sesame, Sorghum, Soybean, & \\
Sunflower, Sunflower Seed, & \\
Tallow, Tea, Thistle,Vernonia, & \\
Walnut, Wheat Germ & \\
\hline
\end{tabular}

intellectual property rights, for example, patents, are central. The fencing of any commons, whether physical or intellectual, follows a basic principle of property rights: valuable property is developed through the investment of human resources, expertise, capital and time, and once value is added the acquisition and assertion of property rights will inevitably follow. ${ }^{9}$

\section{THE EVOLVING US MARKET FOR BIODIESEL AND ALGAL BIODIESEL}

Widespread use of biodiesel is primarily inhibited by the price. Figure 1 displays the price of biodiesel versus petrodiesel over the last 4 years, suggesting that as the price of petrodiesel increases, the price differential decreases, with B100 biodiesel becoming a more commercially competitive option. Production of biodiesel typically involves the following steps: (1) biomass cultivation; (2) oil

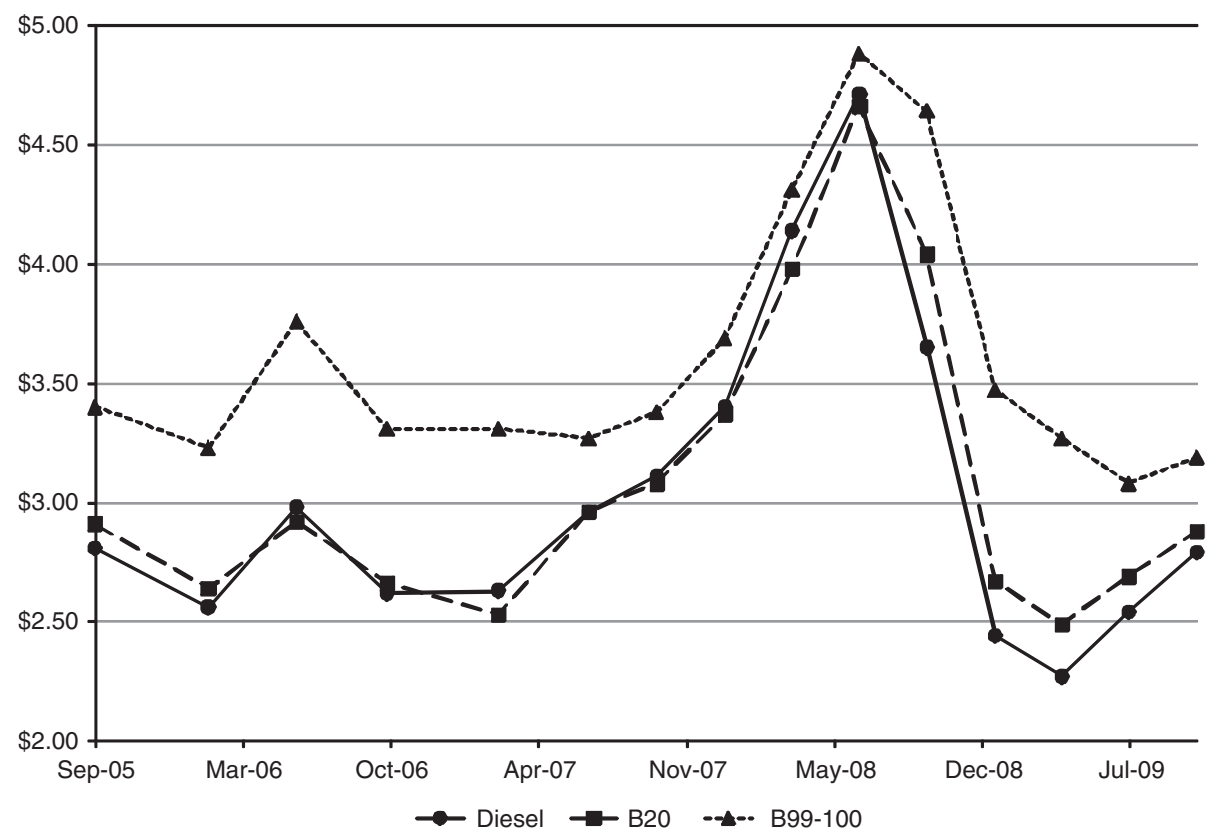

Figure I: United States average prices for diesel and biodiesel blends (B20) and (B99-100). Note: Biodiesel blends are identified with the prefix ' $\mathrm{B}$ ' followed by the percent volume of biodiesel within the blend. For example, B5 is comprised of 5 per cent biodiesel by volume and 95 per cent petrodiesel by volume. ${ }^{10}$ 
extraction and purification; (3) transesterification; and (4) post-processing of biodiesel. Steps (1) and (2), which produce the raw feedstock oil, are integral to the economic viability of biodiesel because these two steps have been estimated to account for approximately 70-90 per cent of the total production cost. ${ }^{11,12}$ For algae, biomass cultivation involves choosing an algal strain, algaculturing and harvesting the algae. The cost of production of algal oil and algal biodiesel are approximately US $\$ 10.60 / \mathrm{gal}$ and approximately $13.25 / \mathrm{gal}$, respectively. ${ }^{8}$ Over the last 5 years, the cost of production for petrodiesel fluctuated between $\$ 2.91 /$ gal and $\$ 1.65 / \mathrm{gal}^{13}$ In order for algal biodiesel to be an economically viable option, there must be major technological advancements and/or government subsidies for research, development and/or production.

Biodiesel has been federally subsidized since 2004. The first biodiesel tax credit was given in the American Jobs Creation Act of 2004. This biodiesel tax credit was extended in 2006, 2008 and 2009. ${ }^{14}$ This current biodiesel federal tax credit expired on 31 December 2009 , causing disruption in the biodiesel industry in early 2010. Recently, the biodiesel industry received a boost from Congress by the passage of the American Workers, State, and Business Relief Act of 2010 in the US House of Representatives and Senate. This Act, if signed into law by President Obama, would retroactively extend the biodiesel tax credit to 31 December 2010. Manning Feraci, Vice President of Federal Affairs for the National Biodiesel Board, commented that the 'retroactive extension of this worthwhile incentive [biodiesel tax credit] will help America realize the job creation, energy security and environmental benefits associated with biodiesel'. ${ }^{15}$ Biodiesel is further supported by individual State incentives in the form of tax credits, refunds and grants. Many states, such as Massachusetts, Minnesota, Oregon and Pennsylvania, have enacted laws mandating all diesel fuels sold to contain $2-5$ per cent biodiesel and the use of biodiesel blends for all state vehicles. ${ }^{16}$
The Energy Independence and Security Act of 2007 (EISA), one of the most important legislative acts for the increased use of algal biodiesel (and biofuels as a whole) in the United States, establishes a Renewable Fuel Standard (RFS) which requires the use of 9 billion gallons of renewable fuel and an annual increase of renewable fuel use to 36 billion gallons in 2022. EISA also requires 21 billion gallons of 'advanced biofuels' capping ethanol from corn starch at 15 billion gallons starting in $2015 .{ }^{17}$ This is a major increase in biofuel use from the previous Act (Energy Policy Act of 2005) which only required 7.5 billion gallons in 2012, increasing to 8.6 billion gallons in $2022 .{ }^{17}$ Algal biodiesel is one of the most promising fuels for meeting the RFS. ${ }^{18}$ The EISA RFS requirements have lead to an increase in algal biodiesel research and investment over the last few years.

Private investment in algal biodiesel has increased, as is evidenced by Sapphire Energy, Inc. raising more than $\$ 100$ million $^{19}$ and Solazyme, Inc. raising $\$ 45.4$ million for algal biodiesel in recent years. ${ }^{20}$ Also, major collaborative efforts, such as the approximately $\$ 600$ million Exxon Mobil and Synthetic Genomics, Inc. collaborative research ${ }^{21}$ and the approximately $\$ 500$ million BP Global, University of California, Berkeley, Lawrence Berkeley National Laboratory, and University of Illinois at Urbana-Champaign consortium, concentrating on algal biodiesel have been approved. ${ }^{22}$ This recent investment in research and development exemplifies the US government's and industry's commitment to the use of algal biodiesel in the future, as well as a focused strategy for rapidly advancing innovations which will facilitate widespread commercial availability of algae-based biodiesel.

In order to further capacitize the research and development of algal biodiesel, the US Department of Energy (DOE) held the National Algal Biofuels Technology Roadmap Workshop in 2008. More than 200 professionals from government, industry and academia were hosted at this workshop to discuss and 
identify barriers to the economical production of algal biofuel. This workshop resulted in the development of a National Algal Biofuels Technology Roadmap draft in 2009. (The DOE has issued a request for information on the Roadmap draft. A final version is forthcoming.) The Roadmap sets forth the concentrated and coordinated research and development needed in order to achieve economical algal biofuel. ${ }^{18}$ The Roadmap identifies algae biology and harvesting as the least developed area of algal biodiesel production, but overall advancements are needed in every area. ${ }^{18}$

Most recently, as part of the American Recovery and Reinvestment Act of 2009, $\$ 786.5$ million has been dedicated directly to biofuel research. A large portion of this federal funding has been directly applied to algal biodiesel, including approximately $\$ 22$ million in Solazyme, Inc., \$25 million in UOP LLC, and approximately $\$ 50$ million with Sapphire Energy, Inc. for algal biodiesel research and development. ${ }^{23,24}$

Interest and investment in algal biodiesel is increasing in the United States. The government, industry and academia are committed to the development of algal biodiesel to reduce the US dependence on petroleum and to encourage a move towards green alternative fuels. Patent protection on new algal biodiesel innovations will be essential to attract investment for further research and development. The accelerating transformation of algae from green slime to 'Green Gold' will increase the value of technological advances and drive even greater patenting activity. ${ }^{25}$

\section{US PATENT LAW AND ALGAE}

Patents are government-granted rights to exclude others from making, using, or selling a new, useful and non-obvious invention. The quid pro quo for being granted limited exclusive rights under a patent is that the science and knowledge behind an invention is dedicated to the public through publication, thereby promoting innovation (as articulated in the Constitution, Article 1, Section 8,
Clause 8: 'To promote the progress of science and useful arts, by securing for limited times to authors and inventors the exclusive right to their respective writings and discoveries'). ${ }^{26}$ Patents are essential to innovation and commercialization because they provide security for investment and encourage public disclosure of the science and technology behind new inventions:

$[\mathrm{P}]$ roperty rights promote innovation by allowing intellectual property owners to prevent others from appropriating much of the value derived from their inventions or original expressions. These rights also can facilitate the commercialization of these inventions or expressions and encourage public disclosure, thereby enabling others to learn from the protected property. ${ }^{27}$

Advancements in technology typically require a large amount of research and development investment; this is especially the case in the green and clean technology industries. The exclusive rights conferred by patents, therefore, provide an incentive to both invent and to invest the requisite time and capital to research, develop and commercialize an invention into a marketable product. Without this exclusivity, individuals and companies could appropriate value from the inventions of others without creativity, labor, or financial investment. $^{27}$

Biodiesel and algal innovations can be protected in the United States by utility patents and plant patents. Utility and plant patents grant the right to exclude others from making, using, offering to sell or selling the patented invention ${ }^{28}$ for 20 years from the patent application filing date. ${ }^{29}$ Utility patents are granted for inventions that are new, useful, non-obvious. Plant patents are granted for any asexually reproducing plant that is new, useful, non-obvious and distinct. ${ }^{30}$ Whereas utility patents can have multiple claims (precise section of patent document that describes what is protected), plant patents only allow a single claim. ${ }^{31}$ Also, plant patents 
Table 2: Patent costs (current as of I April 2010) ${ }^{38}$

\begin{tabular}{|c|c|c|c|c|}
\hline \multirow[t]{2}{*}{ Fees } & \multicolumn{2}{|c|}{ General } & \multicolumn{2}{|c|}{ Small entity } \\
\hline & Utility patent (\$) & Plant patent (\$) & Utility patent (\$) & Plant patent (\$) \\
\hline Basic filing fee & 330 & 220 & 165 & 110 \\
\hline Patent search fee & 540 & 330 & 270 & 165 \\
\hline Patent examination fee & 220 & 170 & 110 & 85 \\
\hline Total filling fee & 1090 & 720 & 545 & 360 \\
\hline \multicolumn{5}{|l|}{ Maintenance fees } \\
\hline At 3.5 years & 980 & 0 & 490 & 0 \\
\hline At 7.5 years & 2480 & 0 & 1240 & 0 \\
\hline At 11.5 years & 4110 & 0 & 2055 & 0 \\
\hline Total maintenance fees & 7570 & 0 & 3785 & 0 \\
\hline Total patent cost & 8660 & 720 & 4330 & 360 \\
\hline
\end{tabular}

are not required to meet the often daunting specification requirements of the utility patent. ${ }^{32}$

A patent may be obtained for 'any new and useful process, machine, manufacture, or composition of matter'. ${ }^{33}$ Whether genetically modified organisms and algae are patentable subject matter has been debated. In the 1980 case Diamond v. Chakrabarty, the Supreme Court declared that 'anything under the sun that is made by man' was patentable. This case specifically declared that living organisms modified by humans are patentable. This broad interpretation of patentable subject matter is the basis for enabling patents on biotechnology innovations including algal innovations. ${ }^{34}$

Protection of plants with utility patents and algae with plant patents was further clarified in later cases. In 1985, the Board of Patent Appeals and Interferences in Ex Parte Hibberd declared plants were eligible for utility patents. ${ }^{35}$ The Supreme Court upheld the Hibberd decision in J.E.M. Ag Supply, Inc. v. Pioneer Hi-Bred International, Inc. in 2001 elaborating further that newly developed plants are within the terms of patentable subject matter despite the passage of other statutes that specifically protect plants (Plant Patent Act and Plant Variety Protection Act). ${ }^{36}$

Plant patents can also be used to protect algae strains. The US Patent and Trademark Office (USPTO) states that '[a]lgae and macro fungi are regarded as plants' for the purpose of obtaining plant patent. ${ }^{37}$ As stated above, plant patents are easier to obtain than utility patents. In addition, plant patents are significantly less expensive to file and maintain (see Table 2). Yet, despite the advantages of obtaining a plant patent on an algae strain, very few have been applied for or granted.

J.E.M. Ag Supply is also important because it held that concurrent plant variety protection and patent (utility or plant) protection can be granted for the same plant. Multiple overlapping intellectual property protection is very advantageous for advancing innovations in plants and algae. Concurrently, a utility patent claiming a method of culturing a specific algae strain and a plant patent claiming that algae strain can be obtained. For example, the USPTO has granted Dr Arthur Nonomura, of the University of California in Berkeley, a plant patent for the 'Ninsei' variety of Botryococcus braunii ${ }^{39}$ and utility patents claiming methods of culturing this variety. ${ }^{40,41}$ Simultaneous protective mechanisms provide stronger exclusive rights, greater incentive to innovate, and an increased opportunity to obtain a return on research and development investment. ${ }^{36}$

Currently, the majority of algae and algal biodiesel patenting activity appears to be in the United States, mainly because of large private and public investment in both academic and industrial research and development. 
However, this will likely shift towards greater international patent filing in foreign jurisdictions such as China and India, as the emphasis on global green energy becomes greater, innovations increase in value, and the feasibility of petroleum as a sustainable fuel source diminishes. It is important to recognize that patents in various national jurisdictions might confer broader or narrower rights, depending on the patent laws and their enforcement.

In December 2009, the USPTO launched the Green Technology Pilot Program to accord special status to patent applications pertaining to environmental quality, energy conservation, development of renewable energy or greenhouse gas emission reduction. ${ }^{42}$ This program follows a similar initiative established by the United Kingdom Intellectual Property Office on 12 May 2009. ${ }^{43}$ According to US Secretary of Commerce Gary Locke, the purpose of the program is to encourage innovation, commercialization, and business and job growth by providing patent protection to new inventions more quickly. This program is expected to reduce the average patent pendency time from about 40 months to 32 months. The USPTO has limited this program to the first 3000 applications filed for under this program. ${ }^{42}$ As of 17 June 2010, 1091 petitions for special status under this program have been filed of which 414 have been granted. ${ }^{44}$

\section{CURRENT PATENTS AND PATENT APPLICATIONS IN ALGAE BIODIESEL}

Commercialization of algal biodiesel is heavily dependent upon patents to incentivize research and development, attract venture capital, and provide return on investment. Whereas an earlier 'intellectual property' (that is, patent) landscape provided a broad overview of patent activity in the entire biofuel industry, this article focuses specifically on patenting activity in algal biodiesel sector of the biofuel industry, which is undergoing rapid growth and substantial investment in
Table 3: Breakdown of patents and patent applications identified by commercial application

\begin{tabular}{lc}
\hline $\begin{array}{l}\text { Areas of algal biodiesel } \\
\text { innovation }\end{array}$ & $\begin{array}{c}\text { Patents and patent } \\
\text { applications identified }\end{array}$ \\
\hline Algae strain & $\mathbf{1 5}$ \\
Botryococcus braunii & 7 \\
Dunaliella tertiolecta & 3 \\
Pseudochoricystis ellipsoidea & 1 \\
Chlorella and others & 4 \\
Algae genetic engineering & $\mathbf{7}$ \\
Algaculture & $\mathbf{6}$ \\
Raceway ponds & 1 \\
Photobioreactors & 5 \\
Algal oil extraction & $\mathbf{8}$ \\
Algal oil to biodiesel processes & $\mathbf{1}$ \\
\hline
\end{tabular}

Bold numbers denote the total number patents and patent applications within the categories and the sum of all subcategory patents and patent applications.

research and development of advanced innovations. ${ }^{45-47}$ The following sections will discuss important representative patents and patent applications that protect the major algal biodiesel innovations under development for commercialization (Table 3).

\section{ALGAE STRAINS}

Selection of algae strains is essential to produce economical algal biodiesel. The DOE's Aquatic Species Program investigated over 3000 viable strains of algae for production of biodiesel based on the strain's robustness, oil content, growth rate and metabolic efficiency between 1978 and $1996 .{ }^{48}$ Efficient production of biodiesel from algae requires selection of algal species that allow maximum biodiesel output per resource input. Cost-effective commercially viable biodiesel production from algae requires utilization of algae species with desirable biomass growth rate, oil production, metabolic production (lipids and hydrocarbons), nutrient input, environmental tolerance and photosynthetic efficiency. ${ }^{8,48}$ From the 3000 strains investigated, 300 strains were identified as having desirable characteristics for biofuel production. ${ }^{48}$ No alga strain has yet to be identified with all the desirable characteristics above. ${ }^{49}$ This section describes utility and 
plant patents (and applications) claiming species of algae with desirable characteristics for the production of biodiesel.

\section{Botryococcus braunii}

One of the most promising alga species for biodiesel production is Botryococcus brannii (B. braunii). Varieties of B. braunii can have oil contents up to 90 per cent (of dry weight). ${ }^{50}$ Different types of $B$. braunii produce different hydrocarbons. B. braunii 'race A' produces alkadiene and alkatriene hydrocarbons. B. braunii 'race B' produces botryococcene (hydrocarbons of the chemical formula $\mathrm{C}_{n} \mathrm{H}_{2 n-10}$ with $n=30-37)$ and methylated squalenes hydrocarbons. B. braunii 'race L' produces hydrocarbons that are inconsistent with race $A$ and $\mathrm{B} .{ }^{51}$ Hydrocracking of crude oil from B. braunii produced a final mixture of $15 \mathrm{wt}$ per cent diesel fuel, 15 wt per cent aviation turbine fuel, $67 \mathrm{wt}$ per cent petrol fuel, and 3 wt per cent residual. ${ }^{52}$ B. braunii is particularly advantageous because its high lipid production causes the cells to float. B. braunii cells with colonies containing a hydrocarbon content less than 5 per cent dry weight remained sunk at the bottom of the culture and colonies with a hydrocarbon content greater than 20 per cent dry weight floated. ${ }^{40}$ A recent Japanese patent claims a species of $B$. braunii that is capable of consistently producing 33 hydrocarbons. ${ }^{53}$

Dr Arthur Nonomura's plant patent for B. braunii variety Showa discloses a distinct algal variety characterized by its ability to produce and secrete large amounts of botryococcene in all growth phases. The total botryococcene production is approximately 30 wt per cent of the dry weight of the biomass. This variety has a rapid growth rate, capable of doubling its total biomass in $<40$ hours. The Showa variety is particularly novel because the colonial matrices secrete hydrocarbons consisting primarily of $\mathrm{C}$ botryococcene, which allows for hydrocarbon recovery without the need to destroy cells. The B. braunii variety Showa plant patent was assigned to University of California, Berkeley. ${ }^{54}$
B. braunii variety Ninsei (a recent plant patent granted to Dr Nonomura) is an algal variety similar to the Showa variety (ability to secrete and produce botryococcene and floatation with high lipid content). ${ }^{53}$

However, Ninsei is distinct from other varieties as it grows at the water surface and is also advantageous for the production of biofuel because it is able to survive in chemically extreme environments in which other algal strains cannot: Ninsei produces hydrocarbons in the presence of ammonia (algal hydrocarbon production typically shuts down in the presence of available ammonia). ${ }^{39,40}$ Applications describing methods for the growth of hydrocarbons in B. braunii variety, Ninsei have been applied for in the USPTO $^{40,41}$ and European Patent Office, ${ }^{55}$ also a Patent Cooperation Treaty application has been filed. ${ }^{56}$ Amaethon Energy, a 2009 biodiesel startup, announced it had licensed the Ninsei variety plant patent from Dr Nonomura. ${ }^{57}$

Dr Nonomura also developed methodologies for culturing of B. braunii and collecting the secreted hydrocarbons. The methodology takes advantage of $B$. braunii floatation caused by hydrocarbon production. B. braunii's floatation is used to separate colonies with high hydrocarbon content from colonies with lower hydrocarbon content. The patent application describes a method for extracting hydrocarbons by the application of pressure to the cells. The preferred embodiment involves the application of pressure to a mat that provides sufficient hydrological shear to extrude the hydrocarbons out of the cells. This embodiment allows extraction of hydrocarbon without destroying the algal cells. The patent application also describes optimal chemical culturing composition and hydrocarbon collection from $B$. braunii variety Ninsei in the presence of ammonia. ${ }^{40}$

\section{Dunaliella tertiolecta}

Chinese patent applications for Dunaliella tertiolecta strains with increased growth rate and chlorophyll content were filed by Xin'ao 
Science and Technology Development Co. Dunaliella tertiolecta is a particularly interesting alga species for biodiesel production because it has a high oil content (36-42 per cent dry weight). ${ }^{58}$ The claimed Dunaliella tertiolecta strains displayed a 5.9 to 17.6 per cent increase in biomass and a 1.0 to 8.9 per cent increase in chlorophyll content. These enhanced characteristics make these strains a much more viable option for algal biodiesel production. The patent applications claiming the enhanced strains also claim methods for developing mutated Dunaliella tertiolecta strains by ultraviolet irradiation, high temperature exposure and exposure to ethylmethane sulphonate. ${ }^{59-61}$

\section{Pseudochoricystis ellipsoidea}

The Marine Biotechnology Institute of Japan discovered the alga species Pseudochoricystis ellipsoidea in hot springs, which offers promise for the commercial production of biodiesel. The algae produce small chain saturated hydrocarbons (10-25 carbons), which have superior burning qualities over the heavier oils made by other algae strains, such as $B$. braunii. The patent for $P$. ellipsoidea has been assigned to Denso Corporation. ${ }^{62}$

\section{Chlorella and others}

Chlorella is one of the most highly researched genera of algae for the production of biodiesel. Chlorella species are a viable algal biofuel biomass because they have a high oil content (15-55 per cent dry weight) and biodiesel production has shown to be highly successful. ${ }^{63}$ Chlorella YJ1 was isolated from secondary discharged water from an urban sewage treatment facility. This species is advantageous because secondary urban sewage can be used as a culturing medium without the need for additional nutrients. Chlorella YJ1 enables concurrent sewage treatment and biodiesel production. ${ }^{64}$

Dr Qiang Hu has filed patent applications claiming novel isolated Chlorella and Pseudochlorococcum species and compositions with specifically claimed genomes and isolated species of the genera Chlorococcum, Scenedesmus, Palmellococcus, Cylindrospermopsis and

Planktothrix. These patents also claim methods for utilizing these species for lipid production, wastewater remediation, waste gas remediation and/or biomass production. The species is cultured to remove nutrients and $\mathrm{CO}_{2}$ from wastewater/gas (controlling environmental pollution) while producing renewable biomass for lipid production that can be used to produce biodiesel. The patent and patent applications also disclose methods for lipid isolation and collection. ${ }^{65-67}$ The breadth and scope of these patents and patent applications portends the early stages of what might later become a 'green gold' rush. ${ }^{25}$

\section{ALGAE GENETIC ENGINEERING}

The first successful genetic manipulation of algae to enhance yield involved the introduction of antibiotic resistance to diatoms. Later, the enzymes Acetyl-Coenzyme A Carboxylase (ACCase) and UDP-glucose pyrophosphorylase (UDPGP) and the genes that encode these enzymes (regulators of hydrocarbon production in algae) were isolated and have been patented. ACCase and UDPGP were the first metabolic/genetic discoveries related to the production of biodiesel via lipid metabolism from algae. ${ }^{18}$ During the DOE's Aquatic Species Program, a method of producing stable genetically transformed algae was developed. ${ }^{68}$ This method was used to genetically manipulate chlorophyll to over-express ACCase and test the effect on lipid biosynthesis and accumulation; however, no significant change in lipid accumulation was observed. ${ }^{49}$ Despite the failure, this was a major step toward the use of transgenic algae for biodiesel production. Genetic engineering will most likely be critical for developing algae strains that embody the enhanced suite of desirable characteristics necessary for cost-effective commercial production of biodiesel.

Increasing production of triglycerides for biodiesel from algae can also be achieved by 
improving solar energy conversion. One method of improving conversion is to minimize the chlorophyll antenna size by suppression of the tla1 gene. The patent by Dr Melis Anastasios and Dr Mautusi Mitra describes a method of decreasing chlorophyll antenna size involving inhibiting the expression of the tla 1 by inserting a tla 1 mutation into the algal genome. ${ }^{69}$

Sapphire Energy (who recently raised greater than $\$ 100$ million for green energy projects ${ }^{19}$ ), in conjunction with the Scripps Research Institute, have applied for patents for genetically engineering ${ }^{70}$ and high throughput screening of genetically engineered algae. ${ }^{71}$ This method involves the insertion of genetic material into algae that specifically produces enzymes for the production of biodiesel hydrocarbons. ${ }^{70}$ The high throughput screening can be used to rapidly identify the genetically engineered algae with the most desirable characteristics. ${ }^{71}$

Solazyme has filed a patent application for Chlamydomonas, Chlorella, Volvox, Phaeodactylum, Dunaliella and Thalassiosira algae that have been genetically engineered to maximize triglyceride production. Algal triglyceride production is enhanced by utilizing antisense or RNA interference targeting algal genes involved in photosynthesis. The targeted genes include those affecting the production and efficiency of light absorbing pigments and light harvesting antenna, modulating photosynthetic activity by signal transduction, regulating chlorophyll biosynthesis and encoding proteins that dissipate absorbed light energy as heat (avoiding deconstruction of antennas under high intensity light). ${ }^{25,72}$ Solazyme has also filed a patent application for a method of identifying genes and engineering organisms that could potentially be used to engineer algae that produce desirable hydrocarbons for easier conversion to biodiesel. ${ }^{73}$

Genetically modifying algae for easier cultivation and extraction is another method for developing economical algal biodiesel. As previously stated, cultivation of biomass and extraction of oil from biomass can make up approximately 70-90 per cent of the total production cost. ${ }^{11,12}$ A patent application assigned to Synthetic Genomics, Inc. (recently having entered into a approximately $\$ 600$ million algal biodiesel research collaboration with Exxon Mobil ${ }^{21}$ ) describes a method for developing and using genetically engineered algae which secrete fatty acids. Several genetically modified algae species can be used in this process. This method is advantageous because the fatty acids can be harvested without destroying the algal cells. ${ }^{74}$

\section{ALGACULTURE}

Large-scale production of algae biomass is generally more expensive than growing food crops. ${ }^{8}$ Algae growth requires available light, $\mathrm{CO}_{2}$, water, nutrients (such as nitrogen, phosphorus, iron and silicon) and temperatures between $20^{\circ} \mathrm{C}$ and $30^{\circ} \mathrm{C}$. Currently, the only practical methods for large-scale algae production are raceway ponds and photobioreactors. ${ }^{8}$

\section{Raceway ponds}

Raceway ponds, used for mass algae culture since the early 1950s, consist of a system of closed-loop recirculation channel that is typically about $0.3 \mathrm{~m}$ deep. The mixing and circulation required to stabilize algae growth and productivity is produced by a paddlewheel. Raceway ponds are relatively inexpensive to build and operate, but typically have lower biomass productivity because of poor mixing, light and $\mathrm{CO}_{2}$ availability, and/or contamination. ${ }^{63}$ There are very few recent patents or patent applications on raceway ponds as most research appears to be on photobioreactors because they are capable of producing a higher biomass concentration and less prone to troublesome contamination.

Waterwheel Factory, Inc., the world's largest water-wheel manufacturer, has applied for one of the few patents for raceway ponds, a curve blade paddlewheel specifically made for algae raceway ponds 
and methods for creating raceway ponds. The paddlewheel is light in weight with an outer paddle portion to be positioned at angle with respect to the center paddle portion, which reduces drag and increases the amount of water moved. ${ }^{75,76}$

\section{Photobioreactors}

Photobioreactor, closed apparatus for algae growth, are essentially designed to overcome some of the problems associated with raceway pond systems. Typically, a single species of algae is cultivated in a photobioreactors. Algae growth is usually higher than raceway ponds because growth problems associated with contamination, $\mathrm{CO}_{2}$ and nutrient availability, and poor mixing can be prevented. Despite being much more spatially efficient, photobioreactors are usually more expensive to develop and maintain than raceway ponds. Disadvantages of photobioreactors include algal wall growth, small illumination areas, difficult scale up, limited mass growth and temperature control. ${ }^{8,63}$

Valcent Products has applied for a patent that propagates algae in long rows of suspended moving plastic bags in a system called VertiGro. The culturing of algae is performed efficiently by sequestering $\mathrm{CO}_{2}$ and by exposing the algae suspension in sufficient light. ${ }^{77} \mathrm{~A}$ pilot for the process has been assembled in a large high-density greenhouse in El Paso, Texas. Valcent CEO Glen Kertz reported that up to 100000 gallons of algal oil a year per acre could be produced with the Vertigro system, compared with '30 gallons/ acre from corn or 50 from soybeans' ${ }^{78}$ However, Kertz's, perhaps optimistic, yields are not consistent with other published estimates. $^{8}$

A2BE Carbon Capture has developed a Carbon Capture and Recycle algal photobioreactor and harvesting machine. Each machine consists of one or more transparent algae-growing tubes with a length between 100 and 600 feet and a width between 10 and 20 feet. The transparent tubes serve as photobioreactors for algae production. The tubes are closed to prevent contamination. The counter-rotating currents that are induced within the tubes ensure maximum exposure of the algae to light. Multifunctional rollers operating on the tubes in both directions serve to clean internal surfaces, degas the media, mix the tube contents and re-suspend algae. Wastewater (containing $\mathrm{NO}_{\mathrm{X}}$ ) and gas (containing $\mathrm{CO}_{2}$ ) can be utilized in the tubes for algae culturing. The tubes produce pure $\mathrm{O}_{2}$ and a concentrated slurry of biomass which can be piped through manifolds and vented or collected. The fully enclosed system prevents water evaporation and percolation, reducing the overall water consumption of the photobioreactor tubes. Bio-harvesting aggregates algae cells into larger, more separable organisms, allowing in situ extraction and continuous production without resorting to batch stressing. ${ }^{79}$ A2BE Carbon Capture estimates that 110 tons of $\mathrm{CO}_{2}$ per acre per year consumption and an overall 6-10 year payoff. ${ }^{80}$

OriginOil, Inc. has applied for a patent for a method and vessel that enhances algae growth. The method and vessel are known by their trademarked names Quantum Fracturing ${ }^{\mathrm{TM}}$ and Helix BioReactor ${ }^{\mathrm{TM}}$, respectively. Since algae strains thrive best in a calm fluid environment, the Quantum Fracturing ${ }^{\mathrm{TM}}$ method attempts to supply $\mathrm{CO}_{2}$ and nutrients needed for algae growth without agitating the water medium surrounding the algae. Micron-sized bubbles of water, $\mathrm{CO}_{2}$ and other nutrients are fractured at very high pressure, creating a slurry. The slurry is subsequently applied to the algal culture in the low pressure Helix BioReactor ${ }^{\mathrm{TM}}$. The pressure differential between the two zones (algal culture and slurry) substantially increases the contact and exchange between the micronized nutrients and the algae cells. This process can theoretically achieve total and instantaneous distribution of nutrients to every alga cell in the culture without fluid disruption or aeration. ${ }^{81}$ The increased contact between the algal culture and slurry enables high absorption of $\mathrm{CO}_{2}$ and nutrients, producing a much greater volume of hydrocarbons. This 
technology makes algae production more commercially viable option. ${ }^{78}$

The OriginOil's Helix BioReactor ${ }^{\mathrm{TM}}$ also enhances algae growth by evenly distributing the light within the algal culture. A low-pressure culture medium is contained on a rotating vertical shaft surrounded by lights arranged in a helix or spiral pattern. Each lighting element is engineered to produce light intensity and frequencies for optimal algae growth. ${ }^{82}$ The Helix BioReactor ${ }^{\text {TM }}$ growth environment enables the algae to replicate exponentially. OriginOil is currently testing low energy light-emitting diodes (LEDs) to serve as the lighting sources. ${ }^{78}$

Other companies have developed culture techniques and vessels for removing the oil extraction step. As described above, Synthetic Genomics, Inc. has filed a patent application describing algae, which have been genetically engineered to secrete fatty acids and the method for harvesting the fatty acid from the algal culture medium. This method is particularly efficient because the fatty acids can be recovered without destroying the algal cells. ${ }^{74}$

\section{ALGAL OIL EXTRACTION}

Many different techniques for extracting oil from algae have been attempted, most of which are neither cost effective nor efficient. Highly dependent on the quality of the algal oil, extraction involves concentrating and separating algae from the culturing medium, then mechanical (such as pressing or ultrasonic cell lysing extraction) and/or chemical (such as solvent or supercritical fluid extraction) oil removal. Aurora Biofuels has applied for a patent that concentrates and isolates algae from culture at the industrial scale. ${ }^{83}$ General Atomics has recently been assigned a patent application proposing a cost effective method for algal oil extraction utilizing steam to rupture cells to release oil. ${ }^{84}$ Many methods appear to attempt to remove the extraction process, such as Synthetic Genomics's patent application mentioned above. ${ }^{74}$ For algal biodiesel to become commercially viable, research and development must focus on efficient and economical extraction of oil or methods that remove the oil extraction step. ${ }^{18}$

\section{ALGAL OIL TO BIODIESEL PROCESSES}

Algal biodiesel is produced by transesterifying the naturally occurring triglycerides in algal oil with a short chain primary alcohol (typically methanol or ethanol). The transesterification process is typically enhanced by the presence of acid catalysts, base catalysts, enzyme catalysts or supercritical conditions. Commercially, biodiesel is predominantly produced via base catalysis, which is fast and relatively inexpensive. However, base catalysis is very sensitive to water and free fatty acid contamination, which can lead to unwanted ester saponification (soap accumulation). Therefore, base catalyzed production requires pre-processing of raw input oils to remove water and free fatty acids. ${ }^{85}$ As algal oil typically contains free fatty acids between 20 and 50 per cent, ${ }^{86}$ the cost of biodiesel production can be significantly reduced by making it less sensitive to such impurities.

The 'Mcgyan' process, wherein algal oil is converted to biodiesel utilizing both catalysis and supercritical conditions, is a major innovation toward more efficient and cost-effective biodiesel production from algae. This process enables quick, reliable and cost-effective conversion of feedstock oil with high free fatty acid content, via continuous transesterification of oil by running mixtures of oil and alcohol through a fixed bed reactor utilizing metal-oxide catalysts. ${ }^{87}$ The Mcgyan process has proven to be very successful, exhibiting a biodiesel conversion rate of greater than 90 per cent for algal oil with a residence time of approximately 60 seconds. Utilizing porous zirconia, titania and alumina microspheres, the Mcgyan Process can be operated industrially with supercritical alcohol for continuous long-term biodiesel fuel production without loss of catalytic activity or conversion rate for greater than 115 hours. ${ }^{86}$

Supercritical alcohol (at conditions greater than critical temperature and pressure, 
displaying both characteristics of a gas and a liquid $^{88}$ ) in the Mcgyan process allows esterification of free fatty acids and transesterification of triglycerides simultaneously with virtually no sensitivity to water content. ${ }^{85}$ The free fatty acid in algal oil is converted to biodiesel by esterification simultaneous with transesterification of triglycerides when utilizing supercritical alcohol in the Mcgyan process. This enables the Mcgyan process to utilize raw algal oil without the need for pre-processing to remove the free fatty acids. ${ }^{87}$ A 25 per cent reduction in cost production is possible if less expensive feedstocks can be used to produce biodiesel (all other production costs kept equal). ${ }^{86}$ The process is capable of producing biodiesel meeting ASTM International (formerly American Society for Testing and Materials) standards at almost $\$ 2$ less per gallon than other biodiesel plants. The process is currently being used commercially by Ever Cat Fuels with the capability of producing 3 million gallons of biodiesel per year. ${ }^{89}$

\section{CURRENT AND FUTURE DEVELOPMENT}

In late 2009, ASTM International approved three new biodiesel blend standards (ASTM D975-08a, ASTM D396-08b and ASTM D7467-08). Specifications ASTM D975-08a (diesel fuel oils used for on- and off-road diesel applications) and ASTM D396-08b (fuel oils used for home heating and boiler applications) were revised to include up to 5 per cent (B5) biodiesel. The ASTM specifications allow regular diesel fuel to be composed of up to 5 per cent biodiesel (B5). Also, ASTM D7467-08 was approved, setting a standard for biodiesel/diesel blends of between 6 per cent (B6) and 20 per cent (B20) biodiesel for on- and off-road diesel applications. These standards should allow biodiesel mixtures to become as commonplace as 10 per cent (E10) ethanol blends. These specifications provide a consistent industry standard, giving companies the information necessary to develop reliable engines, start manufacturing of biodiesel acceptable vehicles, and production of pure biodiesel (B100) for blending. These standards are a major step for greater biodiesel production and use internationally, especially in the US. ${ }^{90}$

\section{CONCLUSION}

The United States is in the early stages of a green revolution. Algal biodiesel is one of the most promising alternative fuels, but more research and development is required for algal biodiesel to become a viable commercial option. Patent protection of new innovations will be essential to the commercialization of algal biodiesel.

This preliminary patent landscape of algal biodiesel technologies suggests that increasing investment in basic research and development is adding value, with a concomitant increase in patent application filing and patent issuance. Notably, there is substantial patenting activity in the fundamental technological building blocks of algal biodiesel technology: feedstock strains and biotechnological engineering and improvement. This strongly supports the precept that property rights follow value, that algal domestication is creating an entirely new value-added commodity, and that the algal commons is less viewed as worthless green slime and more viewed as potential green gold.

In the algal biodiesel technology space, more comprehensive patent landscapes will be needed to determine where opportunities lie for innovation, investment and public-private collaborative research and development. Increased public and private investment will continue to drive the future development and commercialization of economical algal biodiesel, and more intellectual property rights, for example, patents, will certainly follow. However, this might only be a harbinger of even greater assertion of both intellectual property as well as other proprietary rights regimes. Global commercial/market value will drive these trends. 


\section{ACKNOWLEDGEMENTS}

We thank the University of New Hampshire School of Law (formerly the Franklin Pierce Law Center) for providing resources, support and facilities during the preparation of this article, and Professor Jon Cavicchi (ITTI Director of Research) for useful discussion and guidance in the University of New Hampshire School of Law (formerly the Franklin Pierce Law Center) Intellectual Property Library. Matthew R. Preiss thanks Gordon Preiss, for guidance, and Nicole Stockley for help with formatting and document review.

\section{REFERENCES AND NOTES}

1. Hill, J., Nelson, E., Tilman, D., Polasky, S. and Tiffany, D. (2006) Environmental, economic, and energetic costs and benefits of biodiesel and ethanol biofuels. Proceedings of the National Academy of Sciences of the United States of America 103(30): 11206-11210.

2. Pahl, G. (2008) Biodiesel: Growing a New Energy Economy. White River Junction, VT: Chelsea Green Publishing.

3. Rajagopal, D. and Zilberman, D. (2008) Environmental, Economic and Policy Aspects of Biofuels. Hanover, Germany: Now Publishers.

4. Demirbas, A. (2009) Progress and recent trends in biodiesel fuels. Energy Conversion and Management 50: 14-34.

5. Demirbas, A. (2008) Biodiesel: A Realistic Fuel Alternative for Diesel Engines. London: Springer-Verlag London.

6. Thoenes, P. (2006) Biofuels and commodity market - Palm oil focus. Food and Agriculture Organization of the United Nations, http://www .fao.org/es/esc/common/ecg/629/en/full_paper_ English.pdf, accessed 12 May 2010.

7. Hu, Q. et al (2008) Microalgal triacylglycerols as feedstocks for biofuel production: Perspectives and advances. Plant Journal 54: 621-639.

8. Chisti, Y. (2007) Biodiesel from microalgae. Biotechnology Advances 25: 294-306.

9. Heilbroner, R.L. (1979) The Worldly Philosophers. New York: Simon and Schuster.

10. US Department of Energy. (2010) Alternative fuel price report. Alternative Fuels \& Advanced Vehicles Data Center, http://www.afdc.energy .gov/afdc/price_report.html, accessed 12 May 2010.

11. Haas, M., McAloon, A., Yee, W. and Foglia, T. (2006) A process model to estimate biodiesel production costs. Bioresource Technology 97: 671-678.

12. Meng, X., Yang, J., Xu, X., Zhang, L., Nie, Q. and Xian, M. (2009) Biodiesel production from oleaginous microorganisms. Renewable Energy 34: 1-5.
13. US Department of Energy. (2010) Diesel fuel components history. Energy Information Administration, http://tonto.eia.doe.gov/oog/info/ gdu/dieselpump.html, accessed 4 March 2010.

14. Freed, A.J. (2010) Senate inaction causes lingering uncertainty. Biodiesel Magazine March, http://www .biodieselmagazine.com/article.jsp?article_id $=4058$, accessed 7 April 2010.

15. Biodiesel Magazine. (2010) Senate passes biodiesel tax incentive, http://www.biodieselmagazine.com/ article.jsp?article_id=4072, accessed 4 March 2010.

16. US Department of Energy. (2010) Biodiesel incentives and laws. Alternative Fuels and Advanced Vehicles Data Center, http://www.afdc.energy.gov/afdc/fuels/ biodiesel_laws.html, accessed 4 March 2010.

17. Yacobucci, B.D. and Capehart, T. (2009) Selected Issues Related to an Expansion of the Renewable Fuel Standard. Congressional Research Service Report for Congress R40155.

18. US Department of Energy. (2008) National Algal Biofuels Technology Roadmap. US Department of Energy Biomass Program. Draft, http://www1.eere .energy.gov/biomass/pdfs/algal_biofuels_roadmap .pdf, accessed 30 March 2010.

19. Sapphire Energy, Inc. (2008) Sapphire energy builds investment syndicate to fund commercialization of green crude production. 17 September, http:// www.sapphireenergy.com/press-article/67404sapphire-energy-builds-investment-syndicateto/22042-corporate, accessed 7 April 2010.

20. Biodiesel Magazine. (2008) Solazyme receives expansion funding, http://www.biodieselmagazine .com/article.jsp?article_id $=2845 \& q=a l g a e \% 20$ series $\&$ category_id=5, accessed 7 April 2010.

21. Exxon Mobil. (2009) From pond to pump?, http:// www.exxonmobil.com/Corporate/news_features_ 20091001_algae.aspx, accessed 7 April 2010.

22. Sanders, R. (2007) BP selects UC Berkeley to lead $\$ 500$ million energy research consortium with partners Lawrence Berkeley National Lab, University of Illinois, http://www.berkeley.edu/news/media/ releases/2007/02/01_ebi.shtml, accessed 7 April 2010.

23. US Department of Energy. (2009) Secretary Chu announces nearly $\$ 800$ million from recovery act to accelerate biofuels research and commercialization, http://www1.eere.energy.gov/biomass/news_detail .html?news_id=12488, accessed 7 April 2010.

24. US Department of Energy. (2009) 564_Biomass_ Projects, http://www.energy.gov/news2009/ documents2009/564M_Biomass_Projects.pdf, accessed 7 April 2010.

25. Waltz, E. (2009) Biotech's green gold. Nature Biotechnology 27(1): 15-18.

26. McCarthy, J.T., Schechter, R.E. and Franklyn, D.J. (2004) McCarthy's Desk Encyclopedia of Intellectual Property. Washington, DC: The Bureau of National Affairs. 
27. US Department of Justice and the Federal Trade Commission. (2007) Antitrust enforcement and intellectual property rights: Promoting innovation and competiton. April, http://www.ftc.gov/reports/ innovation/P040101PromotingInnovationand Competitionrpt0704.pdf, accessed 21 June 2010.

28. 35 U.S.C. $\$ 271$.

29. 35 U.S.C. $\ 154(\mathrm{a})(2)$.

30. 35 U.S.C. SS 101-103.

31. 37 C.F.R. $\ 1.164$.

32. 35 U.S.C. \ 162.

33. 35 U.S.C. $\$ 101$.

34. Diamond v.Chakrabarty, 447 U.S. 303 (1980).

35. Ex Parte Hibberd, 227 USPQ 443 (Bd. Pat. App. \& Int. 1985).

36. J.E.M. Ag Supply Inc. v. Pioneer Hi-Bred International, Inc., 534 US 124 (2001).

37. United States Patent and Trademark Office. (2007) General information about 35 U.S.C. 161 plant patents. Patents guidance, tools \& manuals. 13 February, http://www.uspto.gov/web/offices/ pac/plant/, accessed 29 March 2010.

38. United States Patent and Trademark Office. (2008) Current fee schedule. USPTO Fee Information, 2 October, http://www.uspto.gov/web/offices/ac/ qs/ope/fee2009september15.htm, accessed 29 March 2010 .

39. Nonomura, A. (2010) Botryococcus algae plant named 'Ninsei'. USPP21091.

40. Nonomura, A. (2009) Methods and compositions for growth hydrocarbons in Botryococcus sp. US20090087889.

41. Nonomura, A. (2006) Methods and compositions for growth of hydrocarbons in Botryococcus sp. US20060252138.

42. Pappas, P. (2009) The US commerce department's patent and trademark office (USPTO) will pilot a program to accelerate the examination of certain green technology patent applications. US Patent and Trademark Office, 7 December, http://www .uspto.gov/news/pr/2009/09_33.jsp, accessed 18 June 2010.

43. Intellectual Property Office. (2009) UK 'Green' inventions to get fast-tracked through patent system. 12 May, http://www.ipo.gov.uk/about/ press/press-release/press-release-2009/press-release20090512.htm, accessed 21 June 2010.

44. US Patent and Trademark Office. (2010) Green petition report summary. 17 June, http://www .uspto.gov/patents/init_events/green_report_ summary.pdf, accessed 18 June 2010.

45. Kamis, R. and Joshi, M. (2008) Biofuel patents are booming. Baker \& Daniels, LLP; January, http:// www.bakerdstreamingvid.com/publications/ Biofuel\%20Report.pdf, accessed 7 July 2010.

46. Mannan, R. (2010) Intellectual property landscape and patenting opportunity in biofuels. Journal of Commercial Biotechnology 16: 33-46.

47. Roderick, J. and Gaze, L. (2009) Innovation hot spots: IP market report Mining Patent Data for Tomorrow's Breakthroughs. Thomson Reuters; June, http://ip.thomsonreuters.com/media/pdfs/ InnovationHotSpots_June2009.pdf, accessed 4 March 2010.

48. Sheehan, J., Dunahay, T., Benemann, J. and Roessler, P. (1998) A look back at the US department of energy's aquatic species program biodiesel from algae. National Renewable Energy Laboratory, July, http://www.nrel.gov/docs/legosti/ fy98/24190.pdf, accessed 24 August 2009.

49. Brennan, L. and Owende, P. (2010) Biofuels from microalgae - A review of technologies for production, processing, and extractions of biofuels and co-products. Renewable and Sustainable Energy Reviews 14: 557-577.

50. Metting, F.B. (1996) Biodiversity and application of microalgae. Journal of Industrial Microbiology and Biotechnology 17(5-6): 477-489.

51. Metzger, P. and Largeau, C. (2005) Botryococcus braunii: A rich source for hydrocarbons and related ether lipids. Applied Microbiology and Biotechnology 66: 486-496.

52. Hillen, L.W., Pollard, G., Wake, L.V. and White, N. (1982) Hydrocracking of the oils of Botryococcus braunii to transport fuels. Biotechnology and Bioengineering 24(1): 193-205.

53. Murakami, N. (1997) New fine alga belonging to genus Botryococcus and its culture. JP9234055.

54. Nonomura, A. (1988) Botryococcus braunii var. Showa. USPP6169.

55. Nonomura, A. (2006) Methods and compositions for growth of hydrocarbons in Botryococcus sp. EP1920062.

56. Nonomura, A. (2006) Methods and compositions for growth of hydrocarbons in Botryococcus sp. WO2006121950.

57. Amaethon Energy. (2009) Amaethon energy, LLC poster presentation. 15 April, http://biotechnology .georgetown.edu/510\%20Poster\%20Presentations/ GROUP11_15APR09_MAIN_15APR2009.pdf, accessed 4 March 2010.

58. Carlsson, A.S., van Beilen, J.B., Moller, R. and Clayton, D. (2007) Micro- and macroalgae: Utility for industrial applications, EPOBIO, September, http://epobio.net/pdfs/0709AquaticReport.pdf, accessed 7 January 2010.

59. Deng, P., Yin, S., Cai, Z., Wu, H., Wang, Y. and Yuan, P. (2009) Mutation algae of Dunaliella with 
high growth rate and a composite mutation breeding method. CN101597571.

60. Deng, P., Yin, S., Cai, Z., Wu, H., Wang, Y. and Yuan, P. (2009) Dunaliella tertiolecta at high growth rate obtained after ultraviolet mutagenic breeding. CN101597570.

61. Deng, P., Yin, S., Cai, Z., Wu, H., Wang, Y. and Yuan, P. (2009) Dunaliella tertiolecta with high growth rate obtained by mutagenesis and breeding of ethylmethane sulphonate. CN101597569.

62. Kurano, N., Sekiguchi, H., Sato, A., Matsuda, S., Adachi, K. and Atsumi, M. (2009) Novel microalga and process for producing hydrocarbon. US20090215140.

63. Brennan, L. and Owende, P. (2010) Biofuels from microalgae - A review of technologies for production, processing, and extractions of biofuels and co-products. Renewable Sustainable Energy Rev 14(2): 557-577.

64. Li, X., Hu, H. and Yang, J. (2009) Chlorella, its cultural method and use of it in bio-diesel production. CN101565675.

65. Hu, Q. and Summerfeld, M. (2010) Novel Chlorella species and uses therefor. US20100021968.

66. Hu, Q. and Summerfeld, M. (2008) Advanced algal photosynthesis-driven bioremediation coupled with renewable biomass and bioenergy production. WO2008144583.

67. Hu, Q., Han, D. and Summerfeld, M. (2010) Novel Pseudochlorococcum species and uses therefor. EP2173854.

68. Dunahay, T., Roessler, P. and Jarvis, E. (1997) Method to transform algae, materials therefor, and products produced thereby. US5661017.

69. Melis, A. and Mitra, M. (2008) Suppression of tla1 gene expression for improved solar conversion efficiency and photosynthetic productivity in plants and algae. US7745696.

70. Mendez, M. et al (2009) Molecule production by photosynthetic organisms. US20090280545.

71. Mayfield, S., O’Neill, B., Mendez, M., Mikkelson, K. and Poon, Y. (2009) High throughput screening of genetically modified photosynthetic organisms. US20090246766.

72. Dillon, H. (2008) Light utilization alteration of photosynthetic microorganisms. US20080124756.

73. Dillon, H. and Wolfson, J. (2005) Genomic proxy microarrays to identify microbial quantitative trait loci. US20050287561.

74. Roessler, P., Chen, Y., Liu, B. and Dodge, C.N. (2009) Secretion of fatty acids by photosynthetic microorganisms. US20090298143.

75. Vitale, B. (2009) Bio-pond algae paddlewheel, http://www.biopondpaddlewheel.com/index.html, accessed 18 December 2009.
76. Vitale, B. (2009) Paddlewheel apparatus. US20090232653.

77. Kertz, M. (2007) Method and apparatus for $\mathrm{CO}_{2}$ sequestration. US20070289206.

78. Marsh, G. (2009) Small wonders: Biomass from algae. Renewable Energy Focus 9(7): 74-76.

79. Sears, J.T. (2007) Closed system bioreactor apparatus. US20070048859.

80. Sears, J. (2009) Utility scale algal based carbon capture. Electric Utility Consultants, Inc. Web Conference; 4 February, http://www.euci.com/ pdf/0209-algae.pdf, accessed 4 March 2010.

81. Eckelberry, N. and Eckelberry, T.R. (2009) Algae growth system for oil production. US20090029445.

82. Shigematsu, S. and Eckelberry, N. (2009) Apparatus and method for optimizing photosynthetic growth in a photo bioreactor. US20090291485.

83. Radaelli, G., Fleischer, D., Vick, B., Caspari, M., Weissman, J. and Rice, D. (2009) Methods for concentrating microalgae. US20090162919.

84. Dunlop, E.H. and Hazlebeck, D.A. (2009) High efficiency separations to recover oil from microalgae. US20090081742.

85. Van Kasteren, J.M.N. and Nisworo, A.P. (2007) A process model to estimate the cost of industrial scale biodiesel production from waste cooking oil by supercritical transesterification. Resources, Conservation and Recycling 50: 442-458.

86. McNeff, C.V. et al (2008) A continuous catalytic system for biodiesel production. Applied Catalysis A: General 343: 39-48.

87. McNeff, C.V., McNeff, L.C., Gyberg, A.E., Yan, B. and Nowlan, D.T. (2008) Methods and apparatus for producing alkyl esters from lipid feed stocks and systems including same. US20080051592.

88. Dondeti, P. and Desai, Y. (1999) Encyclopedia of pharmaceutical technology. In: J. Swarbrick and J. C. Boylan (eds.) Supercritical Fluid Technology in Pharmaceutical Research. New York: Marcel Dekker, pp. 219-248.

89. Kram, J.W. (2008) Minnesota scientists create new biodiesel manufacturing process. Biodiesel Magazine, 21 March, http://www.biodieselmagazine .com/article.jsp?article_id=2231, accessed 4 March 2010.

90. Weaver, J. and Nazzaro, P. (2009) New biodiesel blend specs published by ASTM international. Biodiesel Education Network News, Winter, http:// www.biodiesel.org/news/ben/2009/winter2009.pdf, accessed 3 March 2010.

91. European Patent Office. (2008) Thomson scientific WPI patent family. 29 February, http://www.epo .org/patents/patent-information/about/families/ thomson.html, accessed 8 July 2010. 


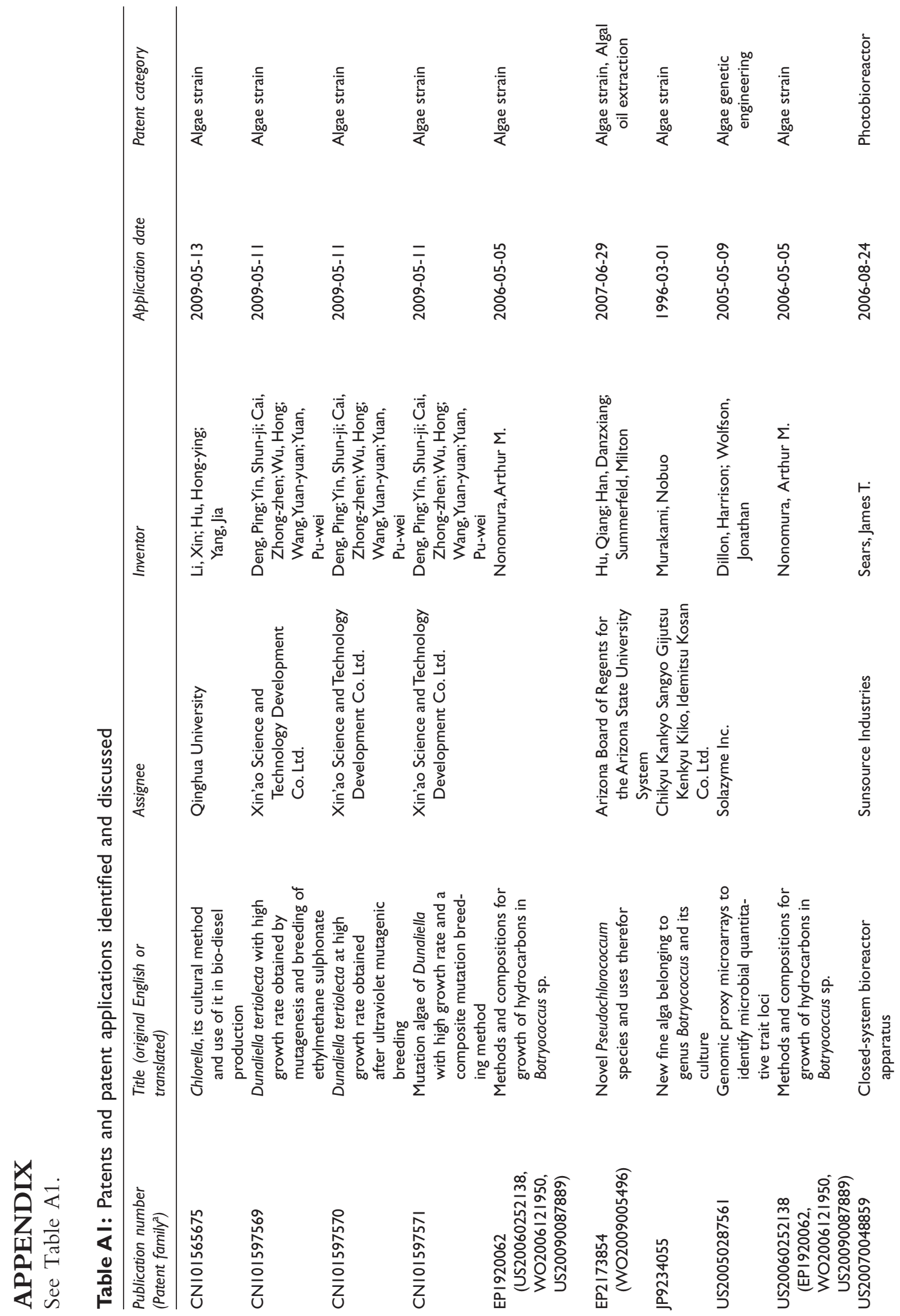




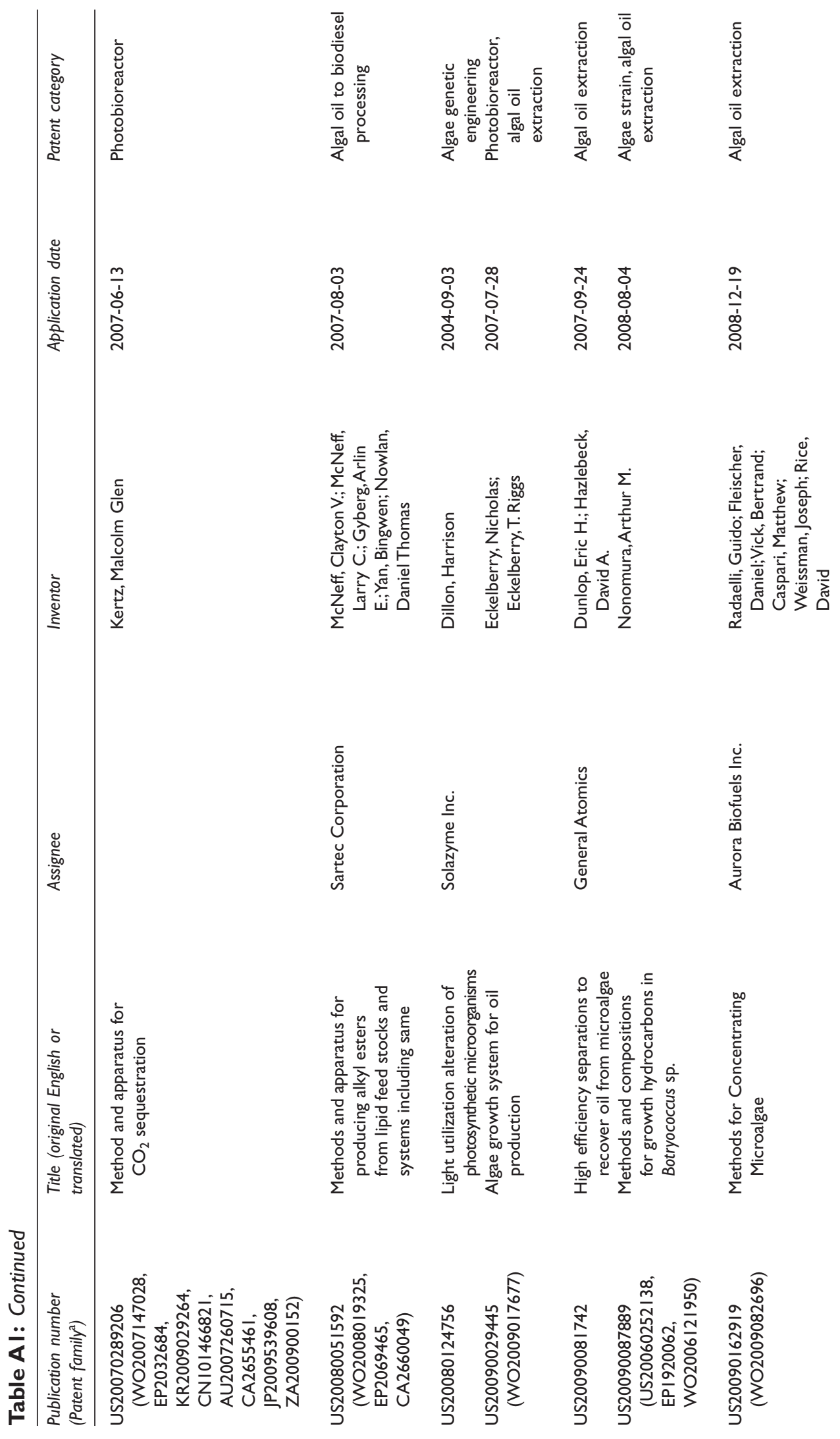




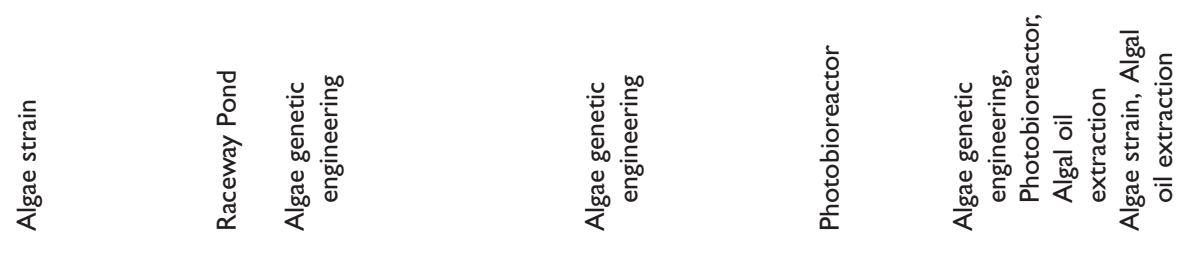

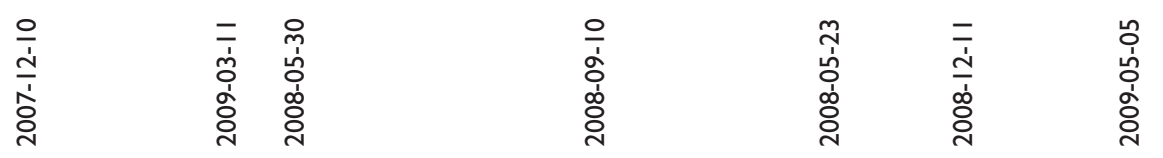

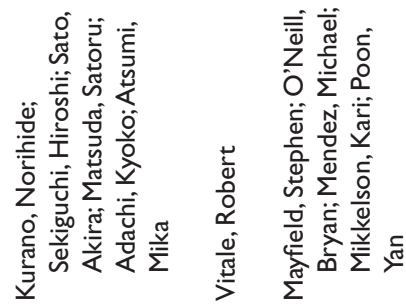

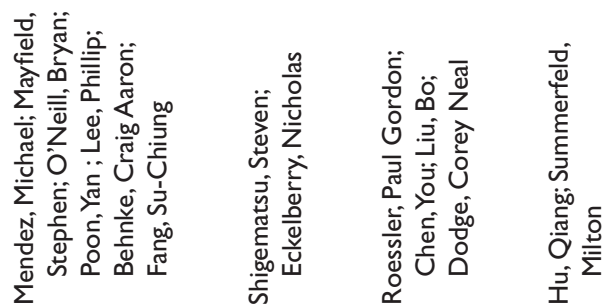
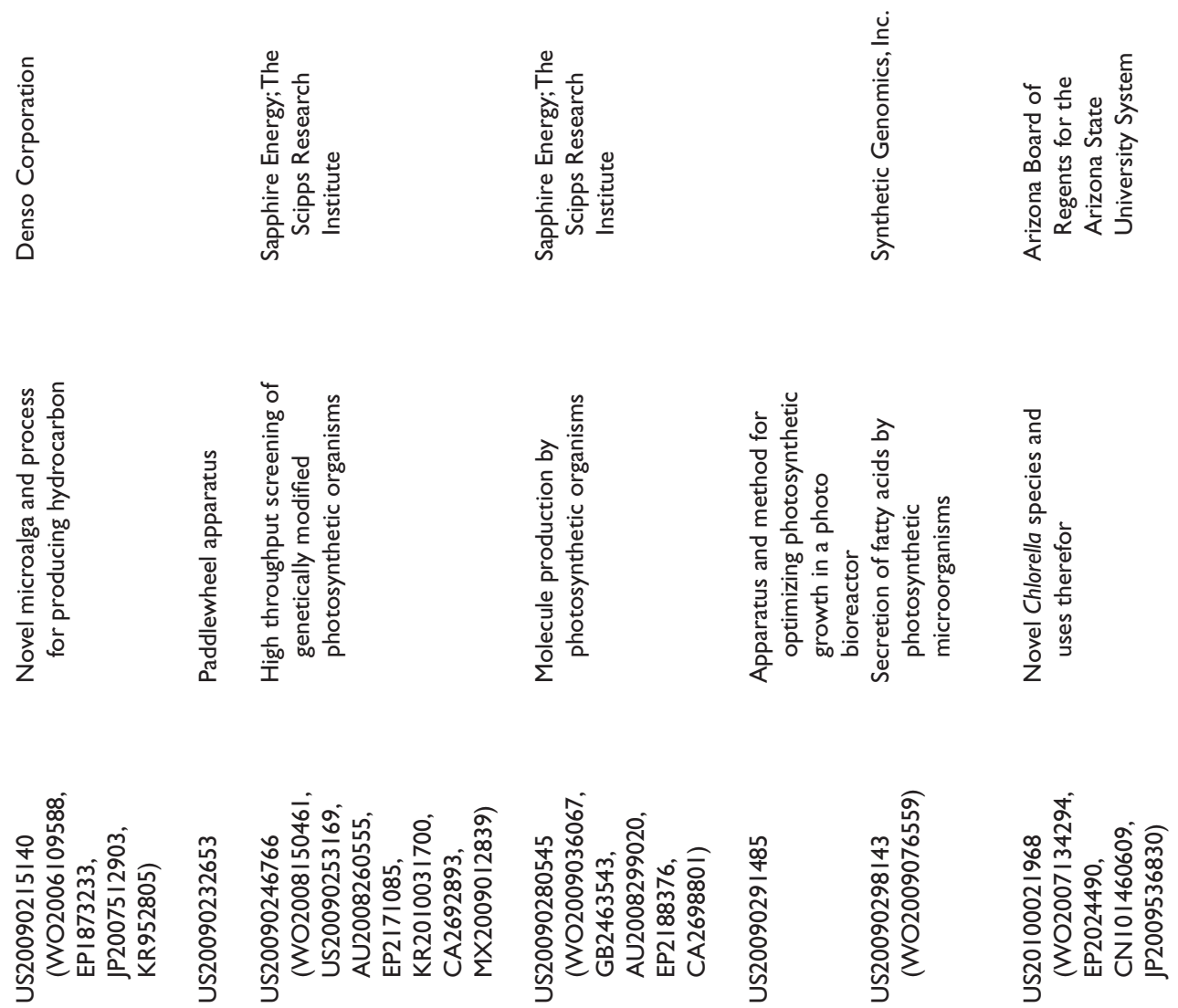


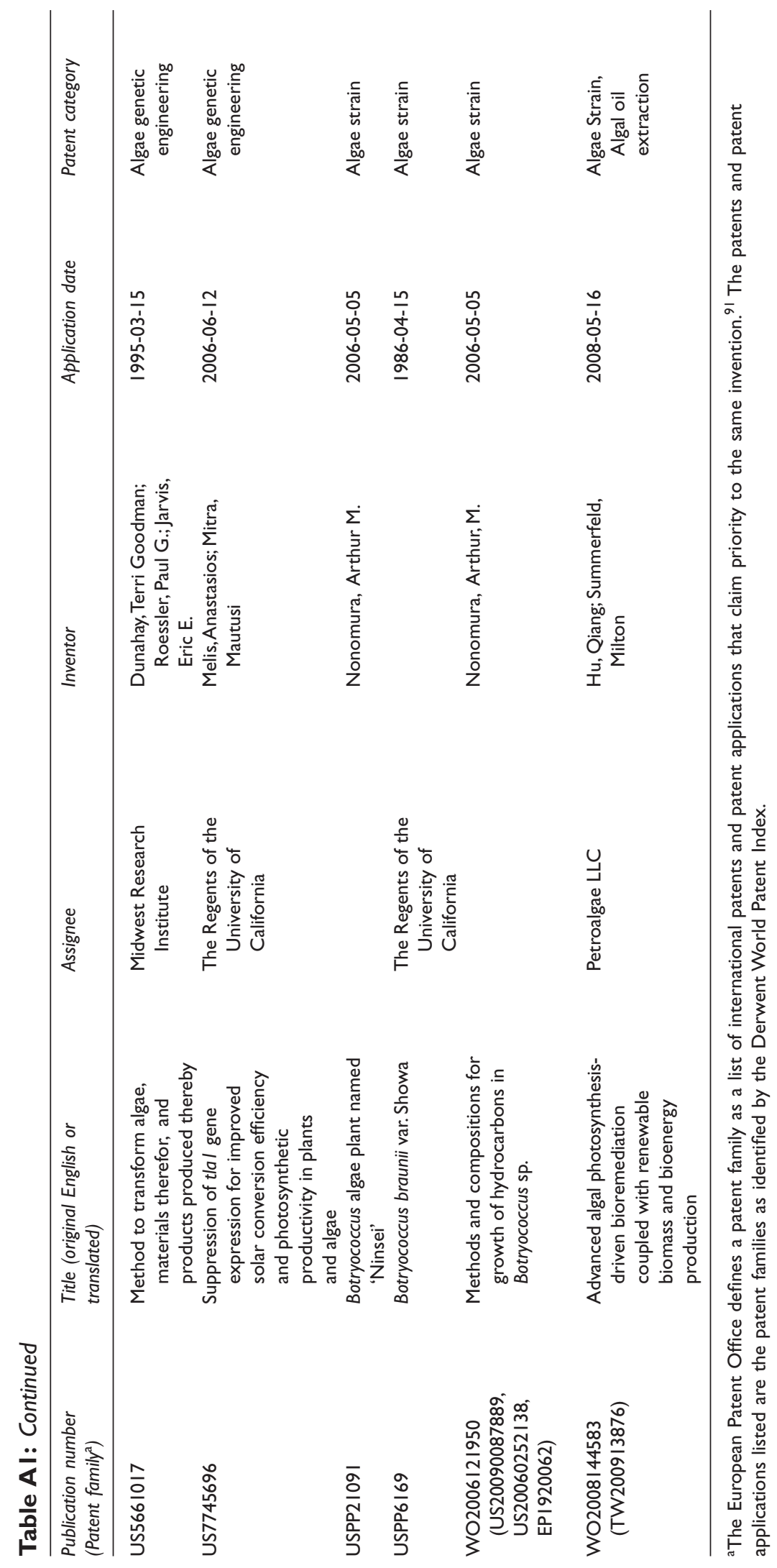

